\title{
Eit evig Russland: Oleg Platonov, Institutt for russisk sivilisasjon og nasjonaliseringa av russisk tenking
}

\author{
Kåre Johan Mjør^
}

Forskar ved Centrum för Rysslandsstudier, Uppsala Universitet, Sverige

\begin{abstract}
This article discusses the Russian nationalist Oleg Platonov and his Institute for Russian Civilization, a project established for publishing both contemporary works and the classics of Russian intellectual history. Special attention is given to how Platonov, who is otherwise known for his extreme anti-Westernism and anti-Semitism, within the framework of this project actively disseminates not only his own idea of a unique and self-sufficient Russian civilization, but also numerous classics of Russian thought, in particular of the Slavophile current. Various Russian thinkers are presented here as the embodiment of "Russian national thought" and the expression of an alleged "ideology of the Russian people". On the basis of this analysis, the article reviews Platonov's contribution to contemporary Russian nationalism more generally and its tendency to make the marginal mainstream.
\end{abstract}

Keywords: Russian Nationalism, Civilizational Theories, Russian philosophy, AntiSemitism, Conspiracies, Reception

Dersom du i dag oppsøkjer ein russisk bokhandel, fysisk eller på nett, for å skaffa deg ei utgåve av ein eller annan kanonisert russisk filosof, er sjansen stor for at det er Institutt for russisk sivilisasjon som er utgjevar av den boka du endar opp med å kjøpa. Dei solid innbundne utgåvene deira, som ser ut til å vera godt påkosta utan å vera avskrekkande dyre, har gjerne ein framståande plass i bokhyllene i filosofiavdelinga i russiske bokhandlar, og dette instituttet har sidan byriinga på 2000-talet nådd å gje ut ei rekkje av dei klassiske tekstane innan russisk tenking, frå mellomalderen til i dag.

Kva slags «institutt» er eigentleg dette? Det engelske Wikipedia omtalar det som ei «tankesmie» (Wikipedia u.d.), men termen er neppe heilt dekkjande, sidan tankesmier er kjenneteikna av møte, nye publikasjonar og eiga forsking om aktuelle politiske emne. Det er lite spor av slik sivilsamfunnsaktivitet på instituttets nettside (Institut russkoj tsivilizatsii u.d. a). Primært er dette instituttet eit forlag: Det

^Kontaktinformasjon: Kåre Johan Mjør. Email: kare.mjor@ucrs.uu.se 
konsentrerer seg om å gje ut bøker, og «hendingane» på nettsida er nettopp offentleggjering av nye utgjevingar. ${ }^{1}$ I tillegg finn vi ei relativt omfattande samling filmsnuttar som primært er omtale av desse publikasjonane. Derimot er sida «spørsmål og svar» tom (eller rettare sagt «under utvikling»), medan sida for peikarar til relaterte prosjekt er påfallande knapp - det finst tilsynelatande få andre internettprosjekt instituttet søkjer å eksplisitt knyta seg til. Du blir heller ikkje oppmoda om å følgja instituttet i sosiale medium. Målt mot det kaotiske og kakofoniske internettet elles gjev sida såleis eit umiddelbart inntrykk av ein relativt låg og avsondra aktivitet.

Det som faktisk møter oss på denne nettsida, er ein logo sett saman av maleriet «Det evige Russland» (1988) av Ilja Glazunov, ein ortodoks kross og ein av katedralane i Kreml. Her ser vi også det som er det fullstendige namnet til instituttet: «Metropolitt av St. Petersburg og Ladoga Ioann-instituttet for russisk sivilisasjon». Dette namnet er utdjupa på sida «Om instituttet»: «Instituttet for russisk sivilisasjon blei skipa i 2003 for å verkeleggjera ideane til og vera til minne om den store forkjemparen (podvizjnik) for det ortodokse Russland Ioann, metropolitt av St. Petersburg og Ladoga» (Institut russkoj tsivilizatsii u.d. b).

Kombinasjonen av Glazunov og metropolitt Ioann er her ein viktig indikator for kva slags ideologisk orientering dette prosjektet har. Glazunov var ein representant for den nye russiske nasjonalismen som vaks fram i Sovjetunionen på 1960-talet under Brezjnev. Bilda hans med motiv frå russisk historie er ofte prega av antivestlege haldningar og har spor av antisemittisme (Brudny 1998: 107-108). Ioann (Ivan Snytsjev) på si side tok over som metropolititt av Leningrad og Ladoga då Aleksej 2 blei patriark i 1990, men han døydde alt i 1995. I løpet av denne tida blei han berømt og berykta for ei rekkje konspiratoriske antivestlege og antisemittiske utsegner om at Russland var under kontinuerleg åtak frå ytre og indre fiendar. Han blei ein leiarfigur for den mest konservative, for ikkje å seia reaksjonære, fløya innanfor den russiskortodokse kyrkja, og fekk ein tydeleg tilhengarskare. I ettertid har leiinga i den ortodokse kyrkja aldri heilt funne ut kva stilling dei skal ta til Ioann, som har verka sterkt polariserande innanfor kyrkja, men som det lenge blei lobbyert aktivt for at måtte kanoniserast (Slater 2000; Knox 2005: 150-154).

Ein person utanfor kyrkja som deler verdsbildet til Ioann, er opphavsmannen til Institutt for russisk sivilisasjon, Oleg Platonov. I tillegg til å ha kalla opp instituttet etter Ioann nemner Platonov ofte Ioann som sin «åndelege lærar» (Zavtra 2010; Russkij vestnik 2014). Også Platonovs tallause bøker krinsar om ulike vestleg-jødiske komplott mot Russland i fortid og notid. No har konspirasjonsteoriar, antisemittiske inkludert, vore utbreidd i det postsovjetiske Russland, og dei ser ut til å få stadig ny kveik av politiske konfliktar heime, men ikkje minst i naboland som Georgia og Ukraina (Ortmann \& Heathershaw 2012; Laruelle 2012; Sakwa 2012). Likevel er Platonovs konspirasjonar, som eg vil koma attende til, av ein såpass ekstrem karakter

\footnotetext{
${ }_{1}^{1}$ Alle publikasjonane til instituttet blir lagt ut fritt tilgjengeleg på nettsida som pdf-filer, du treng dermed ikkje oppsøkja bokhandelen eingong for å skaffa deg publikasjonane deira.
} 
at det er freistande å kategorisera han som marginal: vi har her å gjera med ein konspiratorisk nasjonalistisk antisemitt $i$ periferien av den russiske ålmenta. Konteksten han skaper med metropolitt Ioann i sentrum, kan synast å stadfesta dette: Han knyter seg primært til dei kompromisslause (eller reaksjonære). Han insisterer på at det går føre seg permanente jødiske komplott mot Russland, og det i ei tid der antisemittismen elles generelt har gått noko attende i Russland (medan xenofobi mot andre grupper har auka) (Shlapentokh \& Arutunyan 2013: 59).

Denne artikkelen argumenterer for at å sjå Platonov som utelukkande marginal ikkje er tilstrekkeleg. Poenget er ikkje at Platonov, med sine ekstreme synspunkt og haldningar, er ein viktig eller nødvendigvis mykje lesen tenkjar med direkte påverknad på ålmente og politikk. Derimot vil eg søkja å visa at aktivitetane hans, det vil seia publisering av eigne, men framfor alt av andre sine tekstar, bidreg til å utbre eit bestemt bilde av Russland som ei avgrensa, lukka verd, som det gjeld å verna mot vesten og mot Russlands eigne femtekolonistar, noko som utgjer to sider av same sak. Det sentrale omgrepet han nyttar i denne samanhengen, er nettopp sivilisasjon, noko som knyter han til ein breiare tendens i det postsovjetiske Russland (Sjnirelman 2007; Verkhovskij \& Pain 2010). ${ }^{2}$ Gjennom sine publikasjonar framstiller han russisk idéhistorie (filosofi, ideologi, vitskap) som sjølvstendig, lukka og upåverka utanfrå. Gjennom ein analyse av denne aktiviteten vil eg argumentera for at Platonov er eit særeige døme på det som har vore ein meir generell tendens i dagens russiske nasjonalisme: at det er blitt mogleg å inkludera det marginale og tidvis ekstreme i den dominerande diskursen, som på eitt plan er konsensusorientert gjennom at det blir opna opp for radikale synspunkt side om side med relativt sett meir moderate (Laruelle 2009b), og på eitt anna plan byggjer opp eit manikeisk verdsbilde gjennom si isolasjonistiske haldning og kategoriske avvising av vesten (Sjnirelman 2007: 247).

\section{Platonov og sivilisasjonsnasjonalismen}

Trass i ei tilsynelatande lita interesse for å nytta seg av moglegheitene den nye teknologien byr på til deling og nettverksbygging, kjem nettsida til Institutt for russisk sivilisasjon høgt opp når ein nyttar søkjeordet russkaja tsivilizatsija på søkjemotorar som Google, Yandex eller Rambler. Ho blir stort sett berre slått av Russkaja tsivilizatsija-oppslaget på russisk Wikipedia. Internettsøk på «russisk sivilisasjon», som har blitt eit stadig viktigare omgrep i russiske identitetsdiskursar, fører deg dermed raskt til denne nettsida. Institutt for russisk sivilisasjon er såleis ein sentral nettstad $\mathrm{i}$ den russiske ålmenta, trass $\mathrm{i}$ at han gjer lite ut av seg $\mathrm{i}$ form av diskusjonsforum og annan støy. Du blir i staden presentert for eit rikt utval av tekstar og studiar som dels hevdar å handla om «russisk sivilisasjon», dels hevdar å vera eit uttrykk for «russisk sivilisasjon». $\AA$ utbre perspektivet på Russland som ein eigen

\footnotetext{
${ }^{2}$ Ifølgje ei undersøking Levadasenteret publiserte i april 2015, meiner 55\% av russarar at Russland må finna «sin eigen, særskilde veg», medan 19\% meinte landet burde følgja den «europeiske sivilisasjonen» (Levada-tsentr 2015).
} 
sivilisasjon er såleis ein sentral agenda bak dette prosjektet, og midlet til dette føremålet er å mangfaldiggjera det andre har skrive om Russland - uavhengig av om desse har nytta sivilisasjonsomgrepet eller ikkje.

Platonov er i denne samanhengen ikkje ein av mange som i den seinare tid har kasta seg på ei popularitetsbølgje; han spelar sjølv ei sentral rolle i historia til sivilisasjonsomgrepet i det postsovjetiske Russland. Ifølgje artikkelen om han på instituttets eiga nettside, som inngår i Den store ensyklopedien over det russiske folket, eit prosjekt han sjølv står ansvarleg for, har han vore «den første i russisk vitskap (otetsjestvennaja nauka) som tek i bruk omgrepet 'russisk sivilisasjon' og undersøkjer grundig det indre innhaldet til denne sivilisasjonen» (Institut russkoj tsivilizatsii u.d. d). Platonov må faktisk seiast å ha rett i dette (jf. Sjnirelman 2007: 229) - om vi ser bort frå termen «vitskap». Alt i 1992 publiserte han Den russiske sivilisasjonen, ei bok som har kome i fleire utgåver og variantar sidan. «Russisk sivilisasjon» for Platonov er «Det heilage Russland»: ortodoks spiritualitet, antimaterialisme, kollektivisme. Slike definisjonar er gjennomgåande kontrastert med vestleg individualisme og materialisme. Platonov kan såleis karakteriserast som ein postsovjetisk neoslavofil, då slavofile topos som antiindividualisme og antimaterialisme spelar ei sentral rolle $\mathrm{i}$ definisjonen hans av Russland. Innimellom referer han også til eit anna 1800talstopos, nemleg at det russiske folket og staten har innlemma og verna «små nabofolk» på fredeleg vis (Platonov 1995: 36-37), men russisk sivilisasjon handlar for han likevel primært om det russiske ortodokse folket og mindre om den russiske staten.

Dei som skreiv om russisk sivilisasjon tidleg på 1990-talet, var i hovudsak slike neoslavofile. Ein annan skribent som tidleg tok opp sivilisasjonsomgrepet - etter først å ha skrive fleire bøker om den «russiske ideen» - var Jevgenij Troitskij (Scanlan 1994: 44-49). Platonov og Troitskij kan seiast å ha utvikla ideen om ein «sivilisasjonkonflikt» mellom aust og vest parallelt med Samuel Huntington, og i alle fall Troitskij gav umiddelbart positiv respons på den etter kvart så kjende teorien om clash of civilizations (Troitskij 1994: 8).

På midten av 1990-talet må tenking i sivilisasjonar enno seiast å ha vore eit marginalt fenomen også i Russland, men dette skulle gradvis endra seg i samband med at andre og meir kjende figurar tok opp omgrepet. Kommunistleiaren Gennadij Ziuganov, som likeins først skreiv primært om «den russiske ideen», tok etter kvart også i bruk «russisk sivilisasjon» for å kopla slavofile idear om russisk kollektivisme til visjonar om den russiske staten som den sentrale aktøren i Russlands historie. Ei anna gruppe som byrja å nytta termen, var neoeurasiatane, som ser russisk eller eurasisk sivilisasjon som definert ved imperiet. I tillegg tok den russisk-ortodokse kyrkja til å kalla sitt kanoniske territorium for den «ortodokse sivilisasjonen» (Laruelle 2015: 20-21).

Vi ser såleis frå andre halvdel av 1990-talet oppkomsten av det som skal bli eit grunntrekk ved sivilisasjonsdiskursen - eller det forskarane Aleksandr Verkhovskij og Emil Pain (2010) kallar for «sivilisasjonsnasjonalismen» - i det postsovjetiske Russland: kombinasjonen av ideen om det russiske folkets kollektivisme og spiritualitet, altså ein slags etnisk nasjonalisme, med visjonen om Russland som 
imperium, der Russland i nasjonal forstand er den integrerande aktøren andsynes dei andre nasjonalitetane. I den russiske konteksten kombinerer «sivilisasjon» etnisk og imperial nasjonalisme, seier Verkhovskij og Pain, og er såleis ein konsoliderande term, som det er mogleg for ulike grupperingar å slutta opp om. Denne konsensusen blir ytterlegare styrka av at også «stat» og «imperium» - eller populære termar på russisk som gosudarstvennost og derzjavnost - blir omtalt som russiske «verdiar», på linje med kollektivisme og ortodoks spiritualitet (Sjnirelman 2007: 236-37).

Samanlikna med det tidlege 1990-talet har «sivilisasjon» såleis i stadig større grad blitt kopla nettopp til «stat»: Russland er ein statssivilisasjon (gosudarstvotsivilizatsija). Sistnemnde variant har særleg blitt utvikla i tankesmier med nær tilknyting til Kreml (Laruelle 2009a: 62), og blei i samband med valet i 2012 teken i bruk også av Vladimir Putin sjølv, som i ein ofte sitert avisartikkel definerte Russland som «ein unik sivilisasjon»: ein multietnisk sivilisasjon skapt og bunden saman av det russiske folket og den integrerande kulturen deira. Gjennom dette har det russiske folket vore «statsskapande», dei har skapt ein «statssivilisasjon» (Putin 2012; Mjør 2012). Sidan den tid har sivilisasjonsomgrepet figurert med jamne mellomrom ikkje berre hos offentlege intellektuelle, men også hos statlege representantar som kulturministeren Vladimir Medinskij og hos patriark Kirill (Nakanune 2014; Pravoslavie 2014). Putin på si side har, karakteristisk nok, vore meir moderat i omgangen med «russisk sivilisasjon», men under den årlege pressekonferansen sin $\mathrm{i}$ desember 2014 kalla han Russlands økonomiske utfordringar etter annekteringa av Krim for ei «betaling for det naturlege ønsket vårt om sjølvbevaring som nasjon, som sivilisasjon, som stat» (Prezident Rossii 2014).

Kategoriar som imperium og stat ser såleis ut til å spela ei større rolle i dagens sivilisasjonsdiskurs enn dei gjorde i Platonovs neoslavofile idear på 1990-talet. Rett nok har Platonov fått med seg dette skiftet: I eit intervju frå 2014 med tittelen «Russland skal bli eit imperium» (ei bok med same tittel kom i 2015) kan vi sjå at Platonov nærmast ordrett siterer Putins avisartikkel: «Det russiske folket har skapt ein unik sivilisasjon, og denne unike sivilisasjonen har teke opp i seg mange folk. (...) Russland er ein unik stat, ein unik sivilisasjon» (Russkij vestnik 2014). Han innrømmer også at han «tidlegare tenkte annleis». Før såg han det russiske folket som meir isolert frå andre folk i imperiet. Like fullt dominerer framleis den neoslavofile forståinga av sivilisasjon tenkinga til Platonov. Han vender stadig attende til «spiritualitet» (dukhovnost) når han skal setja ord på kva som er landets viktigaste «ressurs» og «våpen».

Sjølv om denne slavofile tolkinga av sivilisasjon no har kome i skuggen av den statssentrerte, som i seinare tid også har blitt aktivert for å legitimera prosjektet med å integrera det postsovjetiske området i ein eurasisk økonomisk union (jf. Putin 2012), finst det fleire publisistar som til liks med Platonov stadig vekk definerer Russland i tråd med slavofile topoi som ein åndeleg motsetnad til vestleg individualisme og materialisme. Eitt døme er sovjetapologeten Sergej Kara-Murza, som karakteriserer Russland som ein tradisjonalistisk ikkje-vestleg kristen sivilisasjon basert på kollektivisme. Den russiske verdsåskodinga har skapt ein antikapitalistisk sivilisasjon, som stadig vekk kjem under press frå vesten (Kara-Murza 2011). Til liks 
med Ziuganov illustrerer såleis Kara-Murza at høgre/venstre-skiljet ofte ikkje tener som relevant analysereiskap i møtet med russisk nasjonalisme. Platonov definerer seg til ei «høgreside» (Zavtra 2010), men begge sider tenkjer grunnleggjande likt om det russiske folket og om Russland som ein eigen sivilisasjon (Malakhov 2007: 30).

\section{Platonovs konspirasjonar}

Eg har overfor karakterisert Platonov som neoslavofil; ut frå Vladimir Malakhovs typologi over dagens russiske nasjonalisme kan han også karakteriserast som «tradisjonalist og potsjvennik», noko som langt på veg er det same (Malakhov 2007: 31-34). Anastasija Mitrofanova kategoriserer han som «ortodoks fundamentalist», saman med mellom andre metropolitt Ioann, men peikar samstundes på at det russiske i praksis synest å vera viktigare enn det ortodokse for denne gruppa (Mitrofanova 2005: 43, 215).

Platonov er økonom av utdanning, og har gjeve ut fleire bøker innan feltet, særleg då om russisk økonomi og arbeid som særeigne praksisar. Dette blir likevel overskygga av den lange rekkja av bøker om konspirasjonar mot Russland. Den omfattande serien Russlands tornekrans (1995-2001) omhandlar all mogleg undergraving ved jødar og frimurarar av den russiske sivilisasjonen, og inkluderer tjukke bøker som Komplottet til tsarmordarane (1996) og Lovløysas løyndom: Fudaismen og frimurarkapen mot den kristne sivilisasjonen (1998). Ifølgje Platonov-biografien på nettsida til Institutt for russisk sivilisasjon «viser han at vestleg sivilisasjon er ideologisk bygd på verdiane til den jødiske Talmud og er den rake motsetnaden til kristen sivilisasjon» (Institut russkoj tsivilizatsii u.d. d). Boka Kvifor døyr USA: Den hemmelege verdsregjeringa (1999) skreiv han etter å ha vitja landet eit halvt års tid. Platonovs paranoide bøker har blitt karakterisert som gjennomtrengde av «patologisk antiamerikanisme, vanvitige konspirasjonar, apokalyptiske bilde av framtida og fantastiske påstandar om ei framtidig gjenføding av den russiske nasjonen» (Umland 2006: 3).

For Platonov var til dømes 1917-revolusjonen djupt antirussisk. Han var retta mot den russiske sivilisasjonen og det russiske folket. Kven stod så bak? Februarrevolusjonen var i hovudsak frimurarane sitt verk, medan Oktoberrevolusjonen var det vesten og jødane som var ansvarleg for. Dette inkluderer drapet på den siste tsarfamilien. Dei russiske bøndene stod på motsett, «russisk» side. Det Platonov jamleg omtaler som jødane sitt folkemord på russarar, varte fram til Moskvaprosessane. Først då makta Stalin å frigjera Russland frå det jødiske fangenskapet, og fiendane til det russiske folket fekk si fortente straff (King 2006: 216-219, 222; Billington 2004: 86-87). For Platonov (som for metropolitt Ioann) er falskneriet Sions vise protokollar eit sannferdig dokument som har blitt stadfesta av historia, og Platonov har bidrege aktivt til å spreia det i det postsovjetiske Russland (Hagemeister 2006: 247).

Platonovs antisemittisme avgrensar seg likevel ikkje berre til samansverjingar mot Russland; han er jamvel ein Holocaustfornektar. I dette tilfellet går fornektinga ut på ein aktiv reduksjon av talet på jødiske offer (ned til ein halv million) parallelt 
med at russarar blir framstilt som det største offeret for nazismen (Rock 2001). I 1996 publiserte han ei russisk utgåve av ein sentral Holocaustfornektar, sveitsaren Jürgen Graf, si bok Myten om Holocaust, og han har samarbeidd med Graf i samband med fleire konferansar i Russland så vel som i vesten. Graf, som har budd i Moskva sidan byrjinga på 2000-talet då han rømde frå ein dom i Sveits (Atkins 2009: 125), er også med i det «vitskaplege rådet» til Institutt for russisk sivilisasjon, medan Platonov er oppført som medlem i redaksjonsrådet til det revisjonistiske tidsskriftet fournal of Historical Review. ${ }^{3}$

Eit meir lokalt tema i Platonovs antisemittisme finn vi i det han har skrive om Khazarriket, som eksisterte på nordsida av Svartehavet frå 400- til 900-talet, der sentrale medlemmer av eliten på eit seint tidspunkt konverterte til jødedommen. Det har i nyare tid oppstått ein myte om at dette representerte eit trugande jødisk nærvere som særleg på 800-talet blei det første dømet på «jødisk herredøme» over Russland. Denne «myten om khazaråket» finn vi att hos fleire sovjetiske akademikarar, ikkje berre hos kontroversielle figurar som Lev Gumiljov, men også meir ålment respekterte som Mikhail Tikhomirov og Mikhail Artamonov. Myten har sidan blitt aktivt spreidd av nasjonalistiske skribentar som nettopp metropolitt Ioann og Oleg Platonov. Viktor Sjnirelman (2012) har argumentert for at «khazarar» her gjennomgåande fungerer som ein eufemisme for jødar, der khazarriket representerer eit tidleg komplott mot Russland.

Platonov har også gjeve ut boka Myte og sanning om pogromane der jødepogromane i imperietida blir framstilt som russisk sjølvforsvar mot «jødisk terror». Saman plasserer alt dette Platonov ikkje berre innanfor dei under ti prosent av folket som tidlegare russiske undersøkingar har vist er ope og konsekvent antisemittisk over tid, men også innanfor dei rundt ein prosent som er (potensielt) antisemittiske aktivistar (Gudkov 2004: 214-218). ${ }^{4}$ På den andre sida er mykje av dette også antivestlege konspirasjonar, noko som skriv dei inn i eit nett av meir utbreidde påstandar, jamvel frå offisielt hald, om at vesten stadig blandar seg inn i russiske tilhøve (Ortmann \& Heathershaw 2012: 560).

Som det vil gå fram av denne artikkelen, er Platonov ein mann med ei rekkje jarn i elden. I 2013 tok han over som redaktør for den nasjonalistiske avisa Russkij vestnik, som Aleksej Senin starta i 1991. Viktigare med tanke på å nå breiare ut er det han også er medlem av den såkalla Izborsk-klubben, som blei skipa på staden Izborsk i Vest-Russland i september 2012 og som har fått mykje merksemd mellom

\footnotetext{
${ }^{3}$ Graf er einaste ikkje-russiske medlem av instituttets vitskaplege råd. Bortsett frå Jevgenij Troitskij, Aleksej Senin og Igor Sjafarevitsj, som er nemnd andre stader i denne artikkelen, samt Platonov sjølv, er namna i dette rådet heller ukjende, men alle er anten oppført med akademiske gradar/titlar eller er forfattarar. Utover dette blir det sagt at det finst eit styre, oppsynsråd, revisorkommisjon og råd for utetterretta verksemd, men ikkje kven som sit desse organa (Institut russkoj tsivilizatsii u.d. b).

${ }^{4}$ I tillegg til 10\% «opne og konsekvente antisetmittar» opererer Gudkov med ei gruppe med mindre ideologiserte antisemittiske haldningar (15-18\%) samt ein meir latent antisemittisme (25$30 \%$ ), som ofte heng saman med annan type xenofobi (Gudkov 2004: 218-221). Tala til Gudkov stammar frå undersøkingar gjort gjennom 1990-talet.
} 
kommentatorar - noko som truleg er i tråd med intensjonane. Izborsk-klubben er eit forum som har som mål å konsolidera russiske offentlege intellektuelle på den «patriotiske sida», på tvers av usemje og fraksjonar som til dømes etnisk versus imperial nasjonalisme (Laruelle 2016: 58) - sjølv om «imperialistane» likevel må seiast å vera dominerande, medan den nye bølgja av russisk etnonasjonalisme (Kolstø 2014) ikkje er representert. Klubben er leia av den neoimperialistiske forfattaren Aleksandr Prokhanov, og mellom medlemmene finn vi den allstadnærverande Aleksandr Dugin så vel som den meir respekterte historikaren Natalja Narotsjnitskaja; politikarar som Sergej Glazjev og Mikhail Deljagin og elles ei rekkje offentlege intellektuelle, gjerne med tilknyting til akademiske institusjonar. Samt Platonov.

Izborsk-klubben, og ikkje minst leiaren Prokhanov sjølv, var særleg aktiv i samband med 2014-annekteringa av Krim og konfliktane i Donbass. På nettsida og i møte har overtakinga av Krim blitt feira vidt og breitt, parallelt med at russiske styresmakter har blitt innstendig oppmoda om å intervenera (endå) meir aktivt $\mathrm{i}$ Donbass. Platonovs bidrag i samband med konfliktane i Ukraina har vore teksten «Korleis russarar blei gjort til ukrainarar». Platonovs forklaring på at dei som opphavleg var russarar no blir hevda å vera ukrainarar, er, ikkje så overraskande for dei som er kjende med teoriane hans, knytt til den tidlegare «polsk-jødiske okkupasjonen» av det vestrussiske landet (Platonov 2014).

Ein annan Platonovtekst på nettsida til Izborsk-klubben, «Dei unike (nepovtorimye) trekka ved den russiske sivilisasjonen» (Platonov 2010), gjentar det som har vore grunnsynet hans sidan byrjinga på 1990-talet: Den russiske sivilisasjonen er ein «lukka (zamknutaja) åndeleg fellesskap», som oppstod meir enn 1000 år før vår tidsrekning. Han er prega av ortodoks etikk, manglande interesse for eigarskap (nestjazjatelstvo), kjærleik til det gode (dobrotoljubie) og kollektivisme, til dømes i økonomi og arbeid. Russland har tradisjonelt vore heilt sjølvforsynt, hevdar han. Her oppstår det sjølvsagt ein motsetnad mellom sivilisasjonens alder og innføringa av ortodoksien, som fann stad langt seinare. Platonovs svar er at ortodoksien blei vald av det russiske folket fordi han harmonerte med det som alt var russiske grunntrekk, nemleg ein spesifikk, kollektivistisk etikk (Zavtra 2010; Mitrofanova 2005: 43).

To premiss for tekstane til Platonov er at det finst absolutte grenser mellom sivilisasjonar og at det finst ingen mellomting mellom patriotar og femtekolonistar. Paradoksalt nok ser denne unike, lukka russiske sivilisasjonen knapt ut til å ha funnest i rein form, då han kontinuerleg har blitt utsett frå åtak utanfrå. Sivilisasjonar er heile tida i konflikt med kvarandre, og den sentrale konflikten i verda står mellom den «kristne ortodokse russiske sivilisasjonen» og den vestlege. Sistnemnde er ikkje lenger kristen på grunn av den påståtte påverknaden frå den jødiske skriftsamlinga Talmud, som førte til framveksten av kapitalismen i renessansen. Denne konflikten vender stadig attende $\mathrm{i}$ nye former - den kalde krigen var eigentleg ein konflikt mellom sivilisasjonar. Og den russiske sivilisasjonen er i dag det viktigaste hinderet for vestleg dominans og herredøme. Det er såleis, hevdar Platonov, umogleg å studera den russiske sivilisasjonen utan å fokusera på det han måtte vera i konflikt med (Platonov 2010). Dette har han sjølv, medvite eller umedvite, teke konsekvensen av: Platonov snakkar sjeldan om Russland utan å snakka om vesten. Hans evige 
imaginære Russland er dermed langt frå «lukka», men ein invertert projeksjon av eit imaginært jødisk vest. Dess sterkare han insisterer på russisk suverenitet og vestleg kolonialisme, dess meir viser han at han er avhengig av nettopp vesten, noko Vjatsjeslav Morozov (2015) nyleg har vist er karakteristisk for Russlands «postkoloniale identitet» meir generelt.

\section{Platonov som redaktør}

Eit sentralt prosjekt for Platonov på 1990-talet var det omfattande verket Det heilage Russland: Ei ensyklopedisk ordbok over den russiske sivilisasjonen, som kom ut i 2000. Som Simon Franklin har peika på i ein kommentar til dette verket, er det ei bok som allereie gjennom tittel og fysisk framtoning gjev inntrykk av å vera seriøs forsking, «basing itself in the solid, reassuring genre of reference book» (Franklin 2004: 113). Rett nok skaper sjølve tittelen motstridande forventningar: «ensyklopedisk ordbok» konnoterer vitskap, rasjonalitet og objektivitet, medan «Det heilage Russland» peikar $\mathrm{i}$ andre retningar. Like fullt blir vi møtt av ei bok som med solid innbinding presenterer om lag 5000 artiklar fordelt på over 1000 sider med lita skrift og mengder av tilsynelatande faktabasert informasjon. I tillegg kjem plansjar, kart og tabellar, samt kjeldetilvisingar. Sjangersignala er akademiske.

Fleire oppslagsord i denne ensyklopedien om personar og stader i eldre russisk historie ser også heilt greie ut, men så kjem ein tilfeldigvis over artikkelen om Aleksej Senin, som vi så vidt møtte ovanfor. Ikkje berre er han påfallande ung til å bli inkludert her (fødd 1945), han blir også omtalt som redaktør for «den patriotiske avisa Russkij vestnik, som forsvarer dei nasjonale interessene til det russiske folket mot vestens jødisk-frimurariske ideologi» (sitert etter Franklin 2004: 114). Førsteinntrykket står med dette tvillaust for fall - bak eit seriøst ytre blir det brått klart at vi her har å gjera ikkje med nøytral forsking, men med nasjonalisme og antisemittisme $\mathrm{i}$ form av eit oppslagsverk. Tittelen Det heilage Russland får med dette også ny meining. Verket definerer til dømes «Ortodoksi» som den «sanne» varianten av kristendommen, i motsetnad til katolisismen. Og den sanne beraren av ortodoksi er Russland.

Franklins observasjon peikar på noko som har vore eit viktig trekk ved aktiviteten til Platonov i lengre tid, nemleg evna til å skapa ein umiddelbar illusjon av seriøsitet og forsking. Agendaen er ikkje veldig godt skjult (det ville jo ha vore kontraproduktivt), men er heller ikkje heilt opp i dagen - det går an å nytta oppslagsverket til enkle opplysningar om russisk middelalder utan å bli utsett for nasjonalisme og antisemittisme. Denne kombinasjonen av seriøsitet og ideologikamp gjer det mogleg for Platonov å spreia perspektiva sine til eit breiare lag av ålmenta enn kva konspirasjonane hans opererer og vanlegvis får gjennomslag i, utan at hans eigne idear treng bli for påtrengande. Spørsmålet er no om og i så fall korleis Platonovs imaginære russiske sivilisasjon og konspirasjonar verkar inn på den omfattande publiseringa hans av tekstar som i røynda ikkje har noko med hans eigen ideologi å gjera, noko som har vore ein sentral del av aktiviteten til Institutt for russisk sivilisasjon sidan starten. 
Når ein kastar eit blikk på bøkene dette instituttet har gjeve ut sidan 2003, blir ein på nytt slått av den seriøse karakteren til utgåvene. For det første den fysiske framtoninga: Dei solid innbundne bøkene, som ikkje sjeldan er over 1000 sider, er utan tvil kostbare å produsera, utan at det blir opplyst om eventuell finansiell stønad til dette prosjektet, korkje i bøkene eller på nettsida. ${ }^{5}$ At utgåvene er omfattande, viser for det andre til eit anna tillitsskapande trekk: Instituttet reklamerer gjerne med at dei gjev ut eldre tekstar som ofte ikkje har vore publiserte sidan 1800-talet - og dette har dei som regel rett i. Dei gjer såleis tilgjengeleg materiale som ikkje berre ålment interesserte, men jamvel forskarar kan ha nytte av. For det tredje har instituttet ved enkelte høve samarbeida med eller $i$ alle fall lånt namnet til kjende, respekterte forskarar. Utgåva av Domostroj, ei bok frå 1500-talet med instruksjonar om kvardagsleg åtferd, er det filologen Vladimir Kolesov ved statsuniversitetet $\mathrm{i}$ St. Petersburg som står bak (han publiserte denne utgåva første gong i 1990). Samlinga av tekstar etter munken Nil Sorskij (1400-talet) er ved ein annan kjend russisk filolog: Gelian Prokhorov. I siste fall er ikkje ein gong Platonov ført opp som hovudredaktør. Nærveret av respekterte akademikarar aukar sjølvsagt truverdet, sjølv om det er tale om gjenutgjevingar og ikkje arbeid gjort for instituttet. ${ }^{6}$

Med tanke på kva Platonov elles har produsert av konspirasjonar, er det påfallande kor lite diskusjon det har vore i den russiske ålmenta om aktiviteten til Institutt for russisk sivilisasjon. ${ }^{7}$ Det som tradisjonelt har vore det sentrale russiske organet for litteraturomtalar og -kritikk, avisa Literaturnaja gazeta, trykker jamleg nøytrale, mildt rosande notisar av dei nye utgjevingane deira. Her må det leggjast til at denne avisa, som var eit liberalt organ på 1990-talet, gjorde ei konservativ vending på 2000-talet under den nye redaktøren Jurij Poljakov (Marsh 2007: 82) - som for øvrig er medlem av Izborsk-klubben. Avisa har introdusert Platonov og instituttet hans med at dei legg til rette for grundigare kjennskap til slavofilien (Literaturnaja gazeta 2008). ${ }^{8}$

\footnotetext{
${ }_{5}^{5}$ Ein rapport publisert på tampen av 2015 på nettsida DeloRus - ein av få nettstader Institutt for russisk sivilisasjon har peikar til - røper at instituttets aktivitetar i 2015 møtte «alvorlege problem knytte først og fremst til manglande finansiering til å betala for arbeidet til medarbeidarar og spesialistar, så vel som for tenestene til trykkeriet. Dette har forseinka ei rekkje prosjekt og jamvel mellombels stogga nokre av dei» (DeloRus 2015). Heller ikkje her blir det opplyst om kva som finst av finansieringskjelder. Derimot får vi ei lang liste over planlagde utgjevingar frametter - frå 1700talspoeten Gavrila Derzjavin til Den russiske ideologien i Izborsk-klubben. For øvrig blei 2015 avslutta med at instituttet publiserte mellom anna Den russiske doktrinen: Ein statleg ideologi i Putins epoke (Institut russkoj tsivilizatsii u.d. a), eit manifest opphavleg publisert i 2007 og forfatta kollektivt av Vitalij Averjanov og andre ved Institutt for dynamisk konservatisme, ein forløpar for Izborskklubben (Laruelle 2009a).

${ }^{6}$ Det blir aldri opplyst om opphavlege utgåver og eventuelt samtykke til gjenutgjeving frå desse forskarane - utover ein (C) med same årstal som den nye utgåva og namn.

7 Påstanden min byggjer på søk utført i Integrum-databasen i juni 2015 etter diskusjonar om Platonov og aktiviteten hans, særleg som redaktør, der eg gjorde minimalt med funn - utover deskriptive kommentarar som nemnt i det følgjande. Generelt er Platonov ingen aktiv debattant eller nærverande figur i ei større russisk ålmente, samanlikna med mange andre Izborskrepresentantar, men held seg til meir avgrensa fora som (nett-)avisa Russkij vestnik.

${ }^{8}$ Avisa omtaler også Platonovs eigne bøker på gjennomgåande positivt vis. I samband med Stalins epoke frå 2013 blir Platonov karakterisert som «konservator, motstandarar av revolusjonar».
} 
Positiv omtale finn vi også på nettstaden Ortodoksi (Pravoslavie 2011), der det i 2011 blei slått opp at «For første gong sidan 1800-talet kjem arbeida til slavofile tenkjarar i fullstendige utgåver». Ansvarleg for nettstaden Ortodoksi er arkimandritt Tikhon også han i dag medlem av Izborsk-klubben, og dermed ein representant for den russisk-ortodokse kyrkja her. Aktivitetane har fått likande omtale, utan at det blir stilt spørsmål ved det ideologiske grunnlaget for instituttet, på nettstaden Teolog (Bogoslov 2011).

Institutt for russisk sivilisasion står bak fleire seriar, der samtidige ideologar opptrer side om side med tenkjarar frå fortida. Eit døme på dette er serien «Russisk motstand», der vi finn både emigrantfilosofen Ivan Ilin og Aleksandr Prokhanov, i tillegg til Platonov sjølv. Eit hovudprosjekt som instituttet særleg profilerer, er Den store ensyklopedien over det russiske folket, som er planlagt i over 20 tematisk organiserte band, og der det i skrivande stund er komne åtte: Russisk patriotisme, Russisk verdsåskoding, Russisk økonomi, Russisk litteratur, Den russiske staten, Russian ortodoksi, Det russiske ikonet og sjølvsagt Russisk sivilisasjon. Men den serien eg særleg vil ta føre meg her, fordi den er den mest illustrerande for strategien til instituttet, heiter nettopp «Russisk sivilisasjon». Det er her klassikarane i russisk idéhistorie primært blir publiserte. I regelen unngår instituttet dei mest obskure samtidige forfattarane $\mathrm{i}$ denne serien, men også her finn vi, når vi ser nøyare etter, ein del overraskingar som kan minna om dei Franklin blei utsett for.

Serien byrja i 2007, og var dei første åra dominert av 1800-talets slavofili: Ivan Kirejevskij, Aleksej Khomjakov, Ivan og Konstantin Aksakov, Nikolaj Danilevskij, Jurij Samarin. Danilevskij og Khomjakov er sidan komne i nye opplag. I tillegg har det etterkvart kome like omfattande utgåver av mindre kjende slavofile (inkludert panslavistar, potsjvenniki med meir), som litteraturkritikaren Apollon Grigorjev, avisredaktøren Mikhail Katkov, kronikøren Aleksandr Kosjelev, geografen Vladimir Lamanskij, økonomen Sergej Sjarapov, filologane Orest Miller og Aleksandr Gilferding, monarkiteoretikarane Lev Tikhomirov og Dmitrij Khomjakov. I tillegg kjem det eg vil hevda er heilt ukjende 1800-talsslavofile som økonomen Ivan Beljajev, panslavisten Anton Budilovitsj, juristen Vasilij Lesjkov og altmoglegmannen Viktor Askotsjenskij - som alle har fått si separate, omfattande samling tekstar.

Men her finst meir enn berre det som vanlegvis blir gruppert som slavofili. Ei anna gruppe er sølvalderfilosofar som Vladimir Solovjov, Sergej Bulgakov, Nikolaj Berdjajev, Jevgenij Trubetskoj og Georgij Florovskij - alle tenkjarar som av ulike årsaker ikkje ser ut til å passa like godt inn under Platonovs paraply. Ortodokse geistlege frå 1800- og 1900-talet er også breitt representert. Vidare møter vi sovjetiske og postsovjetiske skjønnlitterære forfattarar som Vasilij Belov og Valentin Rasputin og skribentar som Vadim Kozjinov, Igor Sjafarevitsj og Mikhail Lobanov.

Det nærmaste vi kjem ein kritikk, er innrømminga av at Platonovs skildring av Stalin som ein som sigrar over det revolusjonære kaoset med støtte i folket «sjølvsagt ikkje er standard» (Literaturnaja gazeta 2013b). Ifølgje omtalen av ei anna bok, Det russiske folket: Historia, sjela, sigrane (også frå 2013), er Platonov ein som «heile livet har studert den russiske sivilisasjonen, som har forska på Fedrelandet», i ein lang tradisjon av russiske folkloristar og etnografar (Literaturnaja gazeta 2013a). 
Alle var representantar for den nye russiske nasjonalismen som oppstod i den seine sovjetperioden (Brudny 1998). Her finst mellomaldertekstar, frå Nestorkrønika til Ivan den Grufulle, så vel som moderne skjønnlitteratur - kanoniserte forfattarar som Mikhail Lomonosov (rett nok breitt representert også med vitskaplege tekstar), Aleksandr Pusjkin, Nikolaj Gogol, Fjodor Dostojevskij og Fjodor Tjuttsjev. Også 1800-talsforskarar utover dei opplagt slavofile, som pedagogen Konstantin Usjinskij, har blitt publisert, i tillegg til konservative statstenestemenn og byråkratar som admiral Sjisjkov, Mikhail Magnitskij, Rostislav Fadejev, Sergej Uvarov og Konstantin Pobedonostsev.

Sidan dukkar det i denne samansette forsamlinga også opp eksplisitt antisemittisk litteratur, som Sergej Nilus, det vil seia teksten Sions vise protokollar. Ei særleg oppsiktsvekkjande bok i denne kategorien er ei samling tekstar av ortodokse geistlege frå rundt 1900 som også var medlemmer i den høgreradikale organisasjonen «Dei svarte hundre». Mest kjend av desse er Ioann av Kronstadt. Sidan desse også har blitt kanonisert av den russisk-ortodokse kyrkja, har boka fått namnet Svarte hundre-helgenar: Den heilage unionen av det russiske folket. Det mest overraskande møtet $\mathrm{i}$ denne serien som hevdar å presentera teoriar om russisk sivilisasjon, blir dermed ei samling tekstar av Konstantin Kavelin, som vanlegvis er omtalt som ein liberal tenkjar.

No er likevel ikkje lesarar nødvendigvis så opptekne av seriar. Viktigare er det korleis utgjevaren formidlar tekstane. Ut frå det som er sagt ovanfor om Platonovs ideologi og realitetsforståing, blir det eit opplagt spørsmål om dette er noko som blir tredd nedover publikasjonane i avgjerande grad? Svaret er både ja og nei. For å ta neiet først: Tekstane blir i liten grad redigerte. Rett nok er Vasilij Zenkovskijs Den russiske filosofiens historie presentert i utval, og på den korte presentasjonen på kolofonsida - der det i Russland alltid finst ein kort omtale av boka lesaren har føre seg - les vi at denne utgåva berre publiserer «dei delane som handlar om kristen filosofi» og at det blir «medvite utelate omtalen av filosofiske system som er etterlikning (epigonstvo) av vestlege idear og ikkje har å gjera med sann russisk kristen filosofi». ${ }^{9}$ Dette verkar som eit umogleg prosjekt, då Zenkovskij såg den mest originale russiske filosofien nettopp som ein syntese mellom Russland og vesten i form av refleksjonar over ortodoksien konstruert som filosofiske system à la Hegel (Mjør 2009). Like fullt er dei viktigaste kapitla om dei største, ifølgje Zenkovskij, russiske systembyggjande filosofane komne med.

I hovudsak har utgåvene heller ikkje noko kommentarapparat som freistar å pressa lesinga i bestemte retningar, medan fororda gjerne er skrivne av eldre ekspertar. Berdjajev, Bulgakov, Grigorjev, Kirejevskij, Khomjakov, Trubetskoj og Solovjov er alle utstyrte med ein introduksjon skriven av den autoritative filosofihistorikaren

\footnotetext{
${ }^{9}$ For å unngå ein lang og komplisert bibliografi gjev eg i det følgjande ikkje referansar til kvar enkelt utgåve, då alle er å finna under avdelinga for serien «russisk sivilisasjon» på instituttets nettside (Institut russkoj tsivilizatsii u.d. c). Med mindre anna er spesifisert, er kjelda for analysen nedanfor denne nettstaden, og lesaren vil her lett kunna identifisera kvar sitata er frå.
} 
Zenkovskij, noko som styrkar seriøsiteten til utgåvene. ${ }^{10}$ Gogolutgåva har eit forord av ein nolevande Gogolforskar, Vladimir Voropajev ved Moskvas statsuniversitet. Derimot har Pusjkinsamlinga Reis deg, Russland, og rag! fått ein meir forstemmande introduksjon: føreordet her er skrive av Boris Brazol, ein russisk kvoteemigrant, som rett nok var litteraturkritikar og grunnleggjar av Pusjkinselskapet i USA, men som også var ein markert antisemitt, som skal ha stått bak den første amerikanske utgåva av Sions vise protokollar (Marks 2003: 172-174). I forordet hans spelar Pusjkins påståtte kamp mot «løynde samfunn», det vil seia frimurarar, ei sentral rolle. Han avsluttar med å slå fast at Pusjkin, som sjølv hadde vore med i ein losje fram til desse blei forbodne i 1822, blei offer for eit frimurarkomplott.

Det konspiratoriske føreordet til Brazol er såleis meir i kategori med dei skrivne av Platonov sjølv (mellom anna om Ivan Ilin) og av metropolitt Ioann (om Ilarion av Kiev og Ivan den Grufulle). Andre føreord er usignerte. Føreorda til utgåvene varierer såleis mellom det seriøse og ideologiserte, men mange er seriøse nok til at heller ikkje dette er ein stad der prosjektet som heilskap nødvendigvis støyter ein breiare lesarkrins frå seg. Særleg utgåvene av sølvalderfilosofien er lite skjemma av ideologiserte forord.

\section{Kolofontekstens retorikk}

Vi står dermed att med omtalen på kolofonsida, som eg så vidt nemnde i samband med Zenkovskij, som staden der Platonov og instituttet hans først og fremst lèt seg sjølve koma til orde med sine perspektiv. Desse tekstane er i tillegg publiserte på instituttets nettside som omtale av verka og forfattarane, og er tilgjengelege her utan at ein må lasta ned sjølve bokfila. Dei fungerer dermed også som sjølvstendige, leksikonliknande nettartiklar om russiske tenkjarar, og her finn vi i sanning mange oppsiktsvekkande presentasjonar og kontekstualiseringar.

Ein gjennomgangstema i omtalen av slavofile tenkjarar er at dei er forsvarar av russisk sivilisasjon. Ivan Aksakov «forsvarte» nasjonale tradisjonar og ideal, det same gjorde den meir ukjende Anton Budilovitsj. Eit anna ord som går att er det nedsetjande epigonstvo - etterlikning - som også var noko dei slavofile kjempa mot. Lesjkov kjempa mot «epigonisk låning» av vestlege idear i jussen, medan potsjvenniken Nikolaj Strakhov kjempa mot epigonstvo av vestlege idear som demokrati og liberalisme meir generelt. Ivan Kirejevskij, «hadde rett» $\mathrm{i}$ at vestleg materialisme fører til tap av trua, medan Aleksej Khomjakov viste at Russlands oppgåve her i verda er å frigjera menneskeætta frå vestleg påverknad.

Sjølv om dette kan bli einsidig og desse omtalane er tydeleg sympatiske, er likevel ikkje dette nødvendigvis noko misvisande lesing av slavofilien. Langt meir problematisk er kolofonpresentasjonen av sølvalderfilosofane. Vladimir Solovjov blir kontekstualisert i ei linje frå dei slavofile, som han «utviklar». Sentralt for Solovjov var frigjeringa frå individualismen, heiter det, til fordel for «heilskapleg visse» (tselnoe

\footnotetext{
${ }^{10}$ Desse introduksjonane er vanlegvis korte utdrag frå filosofihistoria hans, sjølv om ikkje alle tekstane har vore mogleg å identifisera, til dømes Rozanov-introduksjonen signert Zenkovskij.
} 
znanie) - eit slavofilt tema som spelar ei viss rolle i dei tidlege verka til Solovjov, men ikkje i det verket som faktisk blir publisert av Institutt for russisk sivilisasjon: Rettferdiggjering av det gode, ei seinare avhandling om etikk som går i dialog med Kant og der dei slavofile ikkje spelar noka rolle i det heile. Interessant nok kjem kolofonteksten også med ei åtvaring: Solovjov sin «teurgi», det vil seia tru på menneskeleg medverknad i skaparverket, førte han inn i blindvegar som det utopiske prosjektet om å føra ortodoksi og katolisisme saman. Denne overskridinga av grenser mellom sivilisasjonar blir sjølvsagt avvist.

Liknande kritikk finn vi i omtalen av Berdjajev: Det er mange ting hos han som er uakseptabelt for eit menneske som lever etter ideala til Det heilage Russland, heiter det. Ikkje desto mindre finst her «djupe tankar», og "grunnlaget for desse er den nasjonale russiske filosofien - frå metropolitt Ilarion [1000-talet] til dei slavofile», som er den konteksten Berdjajev her blir skriven inn i. Det som særleg blir framheva hos Berdjajev, er at han avdekka dei «jødiske røtene» til sosialismen, samt hans «profetiske» ord om frimurarane som ei øydeleggjande kraft tufta på judaismen. Frimurarskapen er dessutan antinasjonal: «Det som Berdjajev skreiv om i 1918, har blitt røyndom i dagens europeiske union».

Her er det å seia at redaktørane har framheva eitt spesifikt tema til å bli Berdjajev sin hovudbodskap. I Historia si meining, som er inkludert i denne utgåva, postulerer Berdjajev eit samband mellom jødisk messianisme og moderne sosialisme. Som kristen filosof kritiserer også Berdjajev fleire stader visse element i tradisjonell jødisk tenking, som nasjonal eksklusivitet og avvisinga av Kristus. Berdjajevs samtidige Mikhail Gersjenzon, sjølv ein ikkje-praktiserande jøde, opplevde Berdjajevs idear som noko som potensielt kunne rettferdiggjera jødeforfølging, men i Berdjajevs tekstar meir generelt finn vi både kritikk av jødedommen og av antisemittisme (Horowitz 1994: 506, 512). I denne kolofonteksten blir det derimot implisert at sosialismen (og underforstått den russiske revolusjonen) er jødane sitt verk, noko som blir ei karikert attforteljing av Berdjajev. Når det gjeld kommentaren om frimurarane, skjer det to gonger i det publiserte materialet at Berdjajev nemner dette som ei overnasjonal rørsle, som han distanserer seg frå. Berdjajev, til liks med Solovjov, Bulgakov og andre samtidige religiøse filosofar, formulerte ofte ein dobbel kritikk mot både «kosmopolitisme» og nasjonalisme, og sette fram «nasjonalitet» som eit positivt alternativ til begge. Uansett finn ein hos Berdjajev ikkje noko komplott av den typen instituttet her gier til hovudtema i dei to revolusjonskritiske bøkene hans Ulikskapens filosofi og Historia si meining, begge frå det tidlege 1920-talet.

Dette å gripa fatt i det «iødiske spørsmålet» (som det tradisjonelt har heitt i Russland) uansett kor marginalt det måtte vera i det aktuelle tekstmaterialet, skal visa seg å vera eit gjennomgåande trekk i desse kolofontekstane. Iosif Volotskij er ifølgje både kolofonteksten og tekstutvalet først og fremst ein førar i kampen mot dei «judaiserande» i Novgorod på 1400-talet. Dostojevskijs Ein forfattars dagbok er eit forvarsel om revolusjonen som djevelens verk - godt assistert av jødane. No er det vel kjend at denne samlinga inneheld ei rekkje utfall mot jødar, men her blir Dostojevskijs hovudbodskap at sosialisme og kapitalisme er eit «uttrykk for det jødisk-sataniske idealet». Resten av kolofonteksten består av eit langt antisemittisk 
sitat. Det er dermed ikkje overraskande at det jødiske også er framheva i omtalen av filosofen Vasilij Rozanov. Parallelt med at Rozanov hadde ei positiv oppfatning av jødedomens haldning til seksualitet og familie, kom han også til å formulera antisemittiske idear. Sistnemnde handla likevel ikkje om «sionisme» som ei «antikristen kraft», som Institutt for russisk sivilisasjon hevdar, men om påstått jødisk fascinasjon for blod og ritualmord, noko han la fram i boka fødane si haldning til kjensla og lukta av blod (1914) - ein tekst som for øvrig ikkje er teken med i denne Rozanov-utgåva.

Det «jødiske spørsmålet» står også sentralt i presentasjonen av metropolitt Ilarion av Kiev og hans «Tale om lova og nåden» frå midten av 1000-talet. Det sentrale motivet $i$ denne teksten er tilhøvet mellom den gammaltestamentlege lova og nytestamentlege nåden. Teksten kan dermed seiast å innehalda ein antijødisk teologisk polemikk. For Institutt for russisk sivilisasjon handlar likevel dette verket, som «opnar den russiske litteraturen», først og fremst om det «sentrale politiske problemet» for Ilarion og hans samtidige, nemleg kampen mot «khazaråket», som «ikkje var mindre farleg enn mongolåket». Dette trass i at khazarane ikkje er nemnt i Ilarions tekst i det heile; det kristendommen sigrar over hos Ilarion, er heidenskapen, ikkje judaismen (Franklin 1992: xxxvii-xxxviii).

Denne samanlikninga med mongolåket knyter mellom anna an til ein debatt $\mathrm{i}$ tidsskriftet Voprosy literatury i 1988-89, der Vadim Kozjinov (1988, 1989) sette fram påstanden om at konflikten med khazarane var den avgjerande konteksten for å forstå Ilarions samanstilling av lova og nåden. ${ }^{11}$ Sjølv om Khazarriket hadde gått i oppløysing lenge før Ilarion komponerte teksten sin, hevda Kozjinov at det på midten av 1000-talet fanst etterkommarar av dette riket i Kiev i form av politiske motstandarar av jødisk tru. Kozjinov referer her til sentrale sovjetiske arbeid om khazarane, som hevda at den "offensive khazarske judaismen» framleis var aktiv under Ilarion (1988: 142, 1989: 241). Utgåva til Institutt for russisk sivilisasjon er utstyrt med eit kort føreord av metropolitt Ioann samt ein lengre introduksjon og kommentarar av slavisten Viktor Derjagin (1937-1994), som redigerte ei utgåve av Ilarion i 1994. I dette tilfellet ser vi at også kommentarapparatet er ideologisert, gjennom at khazartemaet er løfta fram fleire gonger.

At Pusjkin «avslørte vondskapen og løgna til frimurarskapen», er ønsketenking frå redaktørane si side. Direkte feilaktig er kolofonomtalen i samband med tekstane til general Rostislav Fadejev, som tente under krigen i Nord-Kaukasus på midten av 1800-talet. Fadejev blir hevda å ha «skapt fred i Kaukasus heilt fram til 1917». Feil blir det likeins å seia om Georgij Florovskij at han i Den russiske teologiens vegar frå 1937 «undersøkjer det religiøse livet til det russiske folket», i og med at «folket» ikkje spelar noka rolle i dette verket. Dermed blir det også misvisande å kalla Florovskijs kritiske analyse for eit «oppslagsverk» (spravotsjnik) om russisk spiritualitet, noko det er lite spor av her.

\footnotetext{
${ }^{11}$ Kozjinovs motstandarar i denne debatten var slavistane Mikhail Robinson og Lidija Sazonova, bidraga deira er å lesa i same nummer av Voprosy literatury som Kozjinov sine.
} 
Ei fast formulering om instituttet på nettsida og i publikasjonar er like fullt at det «studerer historia og ideologien til det russiske folket» (Institut russkoj tsivilizatsii u.d. b). Instituttet let såleis ulike nasjonalistiske idear, inkludert sine eigne, snakka på vegne av folket som deira sanne ideologi, noko som kan karakteriserast som ei postsovjetisk form for «indre kolonisering» (jf. Etkind 2011) så vel som «subalternitet»: Det russiske folket blir snakka for, det snakkar ikkje sjølv (Morozov 2015). Slavofili blir i eit slikt perspektiv framfor alt det russiske folkets eigen kamp mot vesten og mot «løgnaktige» vestlege idear og doktrinar: liberalisme, demokrati, sionisme. Denne kampen må på den eine sida førast mot femtekolonistar. Ivan den Grufulle var, ifølgje kolofonteksten til samlinga Herskaren, ikkje berre «skaparen av ideologien til det russiske monarkiet». Han måtte også kjempa mot ein elite som ville leggja Russland under den katolske kyrkja. «Relativt lite blod» gjekk med i denne kampen, blir det hevda, samanlikna med «liknande omstende» i vesten. Og følgjene av Urotida (1598-1613) ville vore langt verre om ikkje Ivan hadde klart å svekkja dei vestvendte (zapadnikı), som dermed mislukkast $\mathrm{i}$ å få det russiske samfunnet til å «forlata ideala til den russiske sivilisasjonen».

På den andre sida fører den russiske sivilisasjonen også ein kontinuerleg kamp mot ytre fiendar, først og fremst mot USA, som støtta av sine «vesteuropeiske satellittar» stod bak oransjerevolusjonen. Dette trugsmålet blir framheva i omtalen av 1800-talstenkjarane Nikolaj Danilevskij og Lev Tikhomirov, som med dette også blir nøklar til å forstå dagens globalisering. Det same gjeld Sions vise protokollar, eit «aktuelt» verk som lèt oss forstå den «oransjerevolusjonære teknologien». Sions vise protokollar er i kolofonteksten karakterisert som «kan henda det største verket skapt av russarar i det 20. hundreåret». Med denne formuleringa blir det jo faktisk innrømt at det ikkje var «Sions vise», men «russarar» som stod bak dette falskneriet. Samstundes blir dokumentet presentert som seriøs forsking, som «med støtte i hemmelege arkiv avslører programmet til den løynde jødiske regjeringa for verdsherredøme».

Men sjølv om frontane er steile og grensene mellom sivilisasjonar er absolutte, er det mogleg å finna attende frå tidlegare villfaringar. Her kjem Konstantin Kavelin inn, som etter kvart forlét den liberale, vestvendte ståstaden og nærma seg dei slavofile gjennom å fokusera meir på staten og bondekommunen (obsjtsina). Han støtta sjølvherskardømet, og blei ein motstandar av privat eigedomsrett, får vi opplyst. Kavelinutgåva heiter følgjeleg Staten og bondekommunen. Utgjevarane ignorerer med dette at «individet» (litsjnost) heldt fram med å vera ein grunnleggjande kategori også hos den seine Kavelin. Ein meir dekkjande tittel ville såleis vore Staten, bondekommunen og individet. Dette kjem klart fram ikkje berre i tekstmaterialet i utgåva, som faktisk også inkluderer hans viktigaste tidlege, liberale skrifter, men også i den lange og seriøse introduksjonen ved ein relativt ukjend forskar, Valerija Trofimova, som slår fast personlegdomens forrang og Russlands tilhøyrsle til Europa i Kavelins tenking. 


\section{Marginal eller mainstream?}

I fleire intervju har Platonov hevda at prosjektet hans er ei oppgåve han fekk av metropolitt Ioann: å gje ut «alle russiske nasjonale tenkjarar». Ublygt samanliknar han det med dei store månadslesebøkene (Velikie minei-tsjeti) frå midten av 1500talet, som samla alt frå nær og fjern fortid som skulle gjelda som russisk ortodoksi. Tilsvarande har Platonov som mål å samla dei klassiske verka i «russisk nasjonal tenking》 (Literaturnaja gazeta 2008; Zavtra 2010). I skrivande stund er Platonov på god veg, siølv om vi lett ser at dette prosjektet er umogleg å gjennomføra utan grove forvrengingar og feillesingar. Platonov og instituttet hans framstiller den russiske sivilisasjonen som eit tidlaust rom kontinuerleg truga av indre og ytre fiendar: vestvendte, oransjerevolusjonære, jødar og frimurarar. Det er såleis ikkje tilfeldig at illustrasjonen som dominerer nettsida er nettopp Glazunovs «Det evige Russland».

Ei kvar tid har sine utgåver. Under perestrojka og den tidlege postsovjetiske perioden var den viktigaste serien for tidlegare undertrykt filosofi Frå historia til den filosofiske tenkinga vår, også kjent som Vedlegg til tidsskriftet Voprosy filosofii. Dette var utgåver som gjorde sentrale filosofar frå 1800- og det tidlege 1900-talet tilgjengeleg for ålmenta og supplerte dei med eit vitskapleg kommentarapparat av høg kvalitet. Russisk sivilisasjon er ein annan type serie, og reflekterer ei anna tid. Målet er å samla «russisk tenking» frå dei tidlegaste tider til i dag under ein einskapleg paraply, som djupast sett uttrykk for det same: «russisk sivilisasjon», «ideologien til det russiske folket» og kampen mot vesten. Mellom desse seriane har det kome stadig nye enkeltståande utgjevingar av russiske filosofiske tekstar, men dette har ofte vore enkle utgåver, og for mange sentrale filosofar saknar forskarar og andre i dag autoritative utgåver, noko som gjer det mogleg for Platonov å nå endå vidare ut med bøkene sine.

Som peika på innleiingsvis er ikkje Platonov nokon dominerande figur i den russiske ålmenta. Samanlikna med andre Izborsk-representantar som Dugin og Prokhanov vil han for mange vera nokså ukjend. Og då det er eit stadig tilbakevendande spørsmål om den kjende Dugin verkeleg har innverknad (Espedal \& Lindholm 2015; Shekhovtsov 2014), kan ein lett konkludera med at Platonov som tenkjar og debattant ikkje har det. Men eit slikt svar er ikkje uttømmande. Platonov står bak utgåver av klassisk russisk filosofi med potensielt brei lesarkrins, og med dette prosjektet har han funne ein alternativ måte å spreia det manikeiske verdsbildet sitt på, som utfyller hans eigne, langt meir eksplisitt konspiratoriske og polariserande skrifter. Gjennom å publisera klassikarane innanfor russisk filosofi når han utover den i utgangspunktet marginale posisjonen sin og kan jamvel bli rett så respektabel i mange sine auge. I kva grad lesarar av desse bøkene faktisk tileignar seg sivilisasjonsperspektivet, ligg utanfor kva denne artikkelen kan seia noko om, men kombinasionen av konspirasjon og omskriving av historia, som vi i dette tilfellet finn $\mathrm{i}$ kolofontekstar og andre presentasjonar, har vore ein sentral reiskap for å spreia nasjonalistiske idear i det postsovjetiske Russland (Laruelle 2012: 566). 
Då Platonov dukka opp tidleg på 1990-talet, var den radikale nasjonalismen hans nettopp marginal, og han var mellom dei som tilsynelatande representerte ei «tapande side» (jf. Laruelle 2009b: 200). Men sidan den gongen har det marginale og ekstreme blitt mainstream i Russland, gjennom at det slepp til i stadig fleire kanalar og har ein opplagt påverknad, sjølv om det er uvisst kor mykje. Og om Platonov ikkje er like synleg som Dugin, har han med Institutt for russisk sivilisasjon funne ein nisje med potensiell gjennomslagskraft, der han på eige vis held fram med å insistera på Russland som ein eigen, unik sivilisasjon. I tillegg går dette perspektivet på russisk tenking som «nasjonal» og «sjølvtilstrekkeleg» inn i ein langt breiare, isolasjonistisk diskurs i dagens Russland prega av omgrep som «suverenitet», «autonomi» og «nasjonalisering» (Morozov 2015: 141). Dette gjer at prosjektet hans finn gjenklang langt utanfor hans eige, evige Russland, slik det blir dyrka fram på nettsida til Institutt for russisk sivilisasjon.

\section{Om artikkelen}

Denne artikkelen er del av eit pågåande forskingsprosjekt om sivilisasjonsomgrepet i det postsovjetiske Russland. Takk til Alexanderinstitutet i Helsingfors for forskingsopphald hausten 2013 og juni 2015, som har gjort dette prosjektet mogleg.

\section{Litteratur}

Atkins, Stephen (2009) Holocaust Denial as an International Movement. Westport: Praeger.

Billington, James H. (2004) Russia in Search of Itself. Washington DC: Woodrow Wilson Center Press.

Bogoslov (2011) «Knizjnaja palitra». 8. september. Tilgjengeleg på www.bogoslov.ru/text/1938927.html. Lesedato 10. mars 2016.

Brudny, Yitzhak (1998) Reinventing Russia: Russian Nationalism and the Soviet State, 1953-1991. Cambridge: Harvard University Press.

DeloRus (2015) «Glavnye itogi raboty Instituta Russkoj tsivilizatsii v 2015 godu». 29. desember. Tilgjengeleg på www.delorus.com/news/news_detail.php?ID=8681. Lesedato 10. mars 2016 .

Espedal, Tore Engelsen \& Audun Lindholm (2015) «Mellom Kali Yuga og Kreml». Vagant 1: 63-69.

Etkind, Alexander (2011) Internal Colonization: Russia's Imperial Experience. Cambridge: Polity Press.

Franklin, Simon (red.) (1992) Sermons and Rhetoric of Kievan Rus. Cambridge: Harvard University Press.

Franklin, Simon (2004) «Russia in Time» i Simon Franklin \& Emma Widdis (red.) National Identity in Russian Culture: An Introduction. Cambridge: Cambridge University Press (11-29).

Gudkov, Lev (2004) Negativnaja identitsjnost: Statji 1997-2002. Moskva: Novoe literaturnoe obozrenie.

Hagemeister, Michael (2006) «The Protocols of the Elders of Zion and the Myth of a Jewish Conspiracy in PostSoviet Russia» i Jan Herman Brinks, Stella Rock \& Edward Timms (red.) Nationalist Myths and the Modern Media: Cultural Identity in the Age of Globalisation. London: Tauris Academic Studies (243-54).

Horowitz, Brian (1994) «A Jewish-Christian Rift in Twentieth-Century Russian Philosophy: N.A. Berdiaev and M.O. Gershenzon». Russian Review 53 (4): 497-514.

Institut russkoj tsivilizatsii (u.d. a) «Glavnaja». Tilgjengeleg på www.rusinst.ru. Lesedato 10. mars 2016.

Institut russkoj tsivilizatsii (u.d. b) «Ob institute». Tilgjengeleg på www.rusinst.ru/contents.asp?id=1. Lesedato 10. mars 2016 .

Institut russkoj tsivilizatsii (u.d. c) «Trudy instituta: Russkaja tsivilizatsija». Tilgjengeleg på www.rusinst.ru/ articlesoftheme.asp? $\mathrm{rzd}=2 \& \mathrm{tm}=19$. Lesedato 10 . mars 2016.

Institut russkoj tsivilizatsii (u.d. d) «Bolsjaja entsiklopedija russkogo naroda: Russkoe mirovozzrenie: Platonov, Oleg Anatoljevitsj (r. 11.01.1950), issledovatel russkoj i zapadnoj tsivilizatsij». Tilgjengeleg på www. rusinst.ru/articletext.asp?rzd=1\&id=840\&tm=10. Lesedato 10. mars 2016.

Kara-Murza, Sergej (2011) Rossija $i$ zapad: Paradigmy tsivilizatsij. Moskva: Akademitsjeskij proekt. 
King, Francis (2006) «Making Virtual (Non)Sense of the Past: Russian Nationalist Interpretations of Twentieth-Century History on the Internet» i Jan Herman Brinks, Stella Rock \& Edward Timms (red.) Nationalist Myths and the Modern Media: Cultural Identity in the Age of Globalisation. London: Tauris Academic Studies (215-28).

Knox, Zoe (2005) Russian Society and the Orthodox Church. London: Routledge.

Kolstø, Pål (2014) «Russia’s Nationalists Flirt with Democracy». Fournal of Democracy 25 (3): 120-34.

Kozjinov, Vadim (1988) «Tvortsjestvo Ilariona i istoritsjeskaja realnost ego epokhi». Voprosy literatury 12: 130-50.

Kozjinov, Vadim (1989) «Nesostojatelnye ssylki». Voprosy literatury 9: 236-42.

Laruelle, Marlène (2009a) Inside and Around the Kremlin's Black Box: The New Nationalist Think Tanks in Russia. Stockholm: Institute for Security and Development Policy.

Laruelle, Marlène (2009b) In the Name of the Nation: Nationalism and Politics in Contemporary Russia. Basingstoke: Palgrave Macmillan.

Laruelle, Marlène (2012) «Conspiracy and Alternate History in Russia: A Nationalist Equation for Success?». Russian Review 71 (4): 565-80.

Laruelle, Marlène (2015) The «Russian World»: Russia's Soft Power and Geopolitical Imagination. Washington DC: Center on Global Interests.

Laruelle, Marlène (2016) «The Three Colours of Novorossiya, or the Russian Nationalist Mythmaking of the Ukrainian Crisis». Post-Soviet Affairs 32 (1): 55-74.

Levada-tsentr (2015) «Bolsjinstvo rossijan khotjat, tsjtoby Rossija sjla po sobstvennomu puti». 21. april. Tilgjengeleg på www.levada.ru/21-04-2015/bolshinstvo-rossiyan-khotyat-chtoby-rossiya-shla-po-sobstvennomu-puti. Lesedato 10. mars 2016.

Literaturnaja gazeta (2008) «Nam neobkhodim dukhovnyj fundament: Sjest voprosov izdatelju». 30. juli.

Literaturnaja gazeta (2013a) «Pamjat o velikikh russkikh ljudjakh». 23. oktober.

Literaturnaja gazeta (2013b) «Russkoe slovo - sverkhderzjava». 6. november.

Malakhov, Vladimir (2007) Ponaekhali tut .... Otsjerki o natsionalizme, rasizme i kulturnom pljuralizme. Moskva: Novoe literaturnoe obozrenie.

Marks, Steven G. (2003) How Russia Shaped the Modern World: From Art to Anti-Semitism, Ballet to Bolshevism. Princeton: Princeton University Press.

Marsh, Rosalind (2007) Literature, History and Identity in Post-Soviet Russia. Oxford: Peter Lang.

Mitrofanova, Anastasia (2005) The Politicization of Russian Orthodoxy: Actors and Ideas. Stuttgart: Ibidem.

Mjør, Kåre Johan (2009) «Russlands dialektiske forhold til Europa: Vasilij Zenkovskij som idéhistorikar». Nordisk Østforum 23 (1): 49-65.

Mjør, Kåre Johan (2012) «Ein unik sivilisasjon: Russlandsførestellingar før og no». Nytt norsk tidsskrift 29 (3): 237-47.

Morozov, Viatcheslav (2015) Russia's Postcolonial Identity: A Subaltern Empire in a Eurocentric World. Basingstoke: Palgrave Macmillan.

Nakanune (2014) «Minkult razrabotal novye printsipy kulturnoj politiki». 16. april. Tilgjengeleg på www. nakanune.ru/news/2014/4/16/22349206/. Lesedato 10. mars 2016.

Ortmann, Stefanie \& John Heathershaw (2012) «Conspiracy Theories in the Post-Soviet Space». Russian Review 71 (4): 551-64.

Platonov, Oleg (1995) Russkaja tsivilizatsija: Utsjebnoe posobie dlja formirovanija russkogo natsionalnogo soznanija. Moskva: Roman-Gazeta.

Platonov, Oleg (2010) «Nepovtorimye tsjerty russkoj tsivilizatsii». Tilgjengeleg på www.izborsk-club.ru/ content/articles/428/. Lesedato 10. mars 2016.

Platonov, Oleg (2014) «Kak russkikh delali ukraintsami». Tilgjengeleg på www.izborsk-club.ru/content/articles/ 3030/. Lesedato 10. mars 2016.

Pravoslavie (2011) «Vpervye c xix veka polnostju izdajutsia trudy myslitelej-slavjanofilov». 18. mars. Tilgjengeleg på www.pravoslavie.ru/news/45389.htm. Lesedato 10. mars 2016.

Pravoslavie (2014) «Russkij mir - osobaja tsivilizatsija, trebujusjtsjaja sberezjenija, uveren patriarkh Kirill». 8. september. Tilgjengeleg på www.pravoslavie.ru/news/73458.htm. Lesedato 10. mars 2016.

Prezident Rossii (2014) «Bolsjaja press-konferentsija Vladimira Putina». 18. desember. Tilgjengeleg på http:// kremlin.ru/events/president/news/47250. Lesedato 10. mars 2016.

Putin, Vladimir (2012) «Rossija: Natsionalnyj vopros». Nezavisimaja gazeta 23. januar.

Rock, Stella (2001) «Russian Revisionism: Holocaust Denial and the New Nationalist Historiography». Patterns of Prejudice 35 (4): 64-76. 
Russkij Vestnik (2014) «Rossija budet imperiej: Intervju Olega Platonova pravoslavnoj studii 'Rus TV'». 9. januar.

Sakwa, Richard (2012) «Conspiracy Narratives as a Mode of Engagement in International Politics: The Case of the 2008 Russo-Georgian War». Russian Review 71 (4); 581-609.

Scanlan, James P. (1994) «Interpretations and Uses of Slavophilism in Recent Russian Thought»i James P. Scanlan (red.) Russian Thought after Communism: The Recovery of a Philosophical Heritage. Armonk: M.E. Sharpe (31-61).

Shekhovtsov, Anton (2014) «Putin's Brain?». New Eastern Europe 8-9: 72-79.

Shlapentokh, Vladimir \& Anna Arutunyan (2013) Freedom, Repression, and Private Property in Russia. Cambridge: Cambridge University Press.

Sjnirelman, Viktor (2007) «Tsivilizatsionnyj podkhod kak natsionalnaja ideja» i Marlène Laruelle (red.) Sovremennye interpretatsii russkogo natsionalizma. Stuttgart: Ibidem (217-48).

Sjnirelman, Viktor (2012) Khazarskij mif: Ideologija polititsjeskogo radikalizma v Rossii i ee istoki. Moskva: Mosti kultury \& Gesjarim.

Slater, Wendy (2000) «A Modern Day Saint? Metropolitan Ioann and the Postsoviet Russian Orthodox Church». Religion State and Society 28 (4): 313-325.

Troitskij, Jevgenij (red.) (1994) Russkaja tsivilizatsija i sobornost: Sbornik statej. Moskva: AKIRN.

Umland, Andreas (2006) «Alexander Dugin, die Faschismusfrage und der russische politische Diskurs». Russlandanalysen 105: 2-5.

Verkhovskij, Aleksandr \& Emil Pain (2010) «Tsivilizatsionnyj natsionalizm: Rossijskaja versija 'osobogo puti'» i Emil Pain (red.) Ideologia «osobogo puti»v Rossii i Germanii: Istorki, soderzjanie, posledstvija. Moskva: Tri kvadrata (171-210).

Wikipedia (u.d.) «Oleg Platonov». Tilgjengeleg på https://en.wikipedia.org/wiki/Oleg_Platonov. Lesedato 10. mars 2016.

Zavtra (2010) «Russkaja tsivilizatsija». 8. desember. 